\title{
4
}

\section{The Prevalence of Renal Osteodystrophy in Chronic Renal Failure Patients in Urban Niger Delta of Nigeria}

\author{
U. R. Onyemekeihia ${ }^{1}$, C. O. Esume², E. Unuigbe ${ }^{3}$, E. Oviasu'3 ${ }^{3}$ L. Ojogwu ${ }^{3}$ \\ ${ }^{1}$ Renal Unit, Department of Medicine, Central Hospital Warri, Delta State \\ 2Department of Pharmacology and Therapeutics, Delta State University, Abraka \\ ${ }^{3}$ Department of Medicine, University of Benin Teaching Hospital, Benin City \\ Nigeria
}

\section{Introduction}

Chronic renal failure (CRF) is defined as a progressive and persistent deterioration in renal function with serum creatinine consistently greater than $175 \mu \mathrm{mol}$ (Adelakun and Akinsola, 1988). It occurs as the termination of many chronic renal diseases, and is an important cause of morbidity and mortality in Africa (Kadiri, 2001). End stage renal failure may be defined as creatinine clearance of less than $10 \mathrm{mls} /$ minute or sustained plasma creatinine concentration above 500pmol/1 (Ojogwu, 2001).

In United Kingdom the prevalence of chronic renal failure is approximately 600 individuals per million population per year $(0.06 \%)$. The incidence of end-stage renal failure is of the order of 200 per million population per year (0.02\%) (Baker, 1999).

In Nigeria, although accurate figures are not available, the size of the problem has been estimated using hospital admission records (Kadiri, 2001). Hospital admission rates of CRF in South West Nigeria were reported as between 6.7\%-8\% (Akinsola et al, 1989; Kadiri and Arije, 1999). However, much earlier reports by Adetuyibi et al showed that CRF accounted for $11.4 \%$ of deaths on the medical wards of a major teaching hospital in the region (Adetuyibi et al, 1976).

Chronic glomerulonephritis and hypertension account for majority of CRF cases in Nigeria, with diabetes mellitus, obstructive uropathy and autosomal dominant polycystic kidney disease accounting for smaller proportions (Akinsola et al, 1989). Chronic interstitial nephritis is thought not to be a common cause of CRF in Nigeria and other parts of Africa (Gold et al 1990, Ojogwu 1990, Mate-Kole et al 1990). Once established, chronic renal impairment tends to progress inexorably to end-stage renal failure, but the rate of progression depends on the underlying aetiology: for example chronic glomerulonephritis leads to a more rapid deterioration compared with chronic tubulointerstitial nephropathies (Baker, 1999). Chronic renal failure is associated with widespread complications, and renal osteodystrophy (ROD) is one of such complications (Hartmut and Marie-Claude 1990). ROD develops in the early stages of loss of the excretory functions of the kidney, and can begin many years before its symptoms and radiological changes appear in adults (Hartmut and 
Marie-Claude 1990). Symptoms of ROD are seen only in about $10 \%$ of pre-dialysis patients, but when they have been on dialysis for several years, $90 \%$ of them will have symptoms (Sanchez 2001). When glomerular filtration rate (GFR) falls to $50 \%$ of normal, more than $50 \%$ of patients exhibit abnormal bone histology. As much as $90 \%$ of patients with end-stage renal failure on maintenance haemodialysis have abnormal bone history.

The bone disorders associated with chronic renal failure are; Osteitis Fibrosa cystica due to secondary hyperparathyroidism, osteomalacia, osteoporosis. Adynamic osteopathy, skeletal microglobulin amyloid deposit, aluminum related low turnover bone disease and mixed forms of ROD. Osteitis Fibrosa is the commonest form of ROD (Hartmut and Marie-Claude 1990). All these increase the morbidity and mortality in patients with CRF. The prevalence of the different types of ROD may vary depending on aluminum exposure, treatment with Vitamin D metabolites, dietary intake, and whether or not is undergoing dialysis (Hartmut and Marie-Claude 1990).

The diagnosis of ROD can either be by invasive or non invasive methods. The invasive methods include: bone biopsy after double tetracycline labeling, scintigraphical scan studies, computed tomography and bone densitometry (Sanchez 2001). A definitive diagnosis of ROD can only be made with bone biopsy. The non invasive methods employ the use of serum markers of bone metabolism, including bone-specific alkaline phosphatase (bap), pre collagen type 1 carboxy1- terminal extension peptide (PICP), osteocalcin, pyridinoline (PYD), tartrate resistance acid phospatase (TRAPE) and intact parathyroid hormone (IPTH), and skeletal x-ray (Sanchez 2001). Indeed, detection of biochemical makers such as serum bap can predict the presence of ROD. Serum bap is a specific and sensitive marker that is used to evaluate the degree of bone remodeling in uraemic patients (Sanchez 2001, Urena et al, 1991). Also intact PTH and several relatively new bone markers such as PYD and PICP are of immense value in the non-invasive diagnosis of ROD. In patients that do not have liver disease, parathyroid hormone and alkaline phosphatase are less expensive and noninvasive alternatives for evaluation of ROD (Urena et al, 1991). These biochemical markers have the added advantage of allowing for repeated measurements, and therefore make possible the study of short term changes in bone turn over and the effect of treatment (Coen et al 1998). They may be used to predict the risk of fracture (independently of bone loss), Rate of bone loss and also the response to therapy (Coen et al 1998).

In developing countries like Nigeria, these non-invasive and relatively less expensive methods for evaluating bone changes in CRF patients will be a very useful alternative to the invasive and relatively more expensive method used in developed counties.

Because of paucity of data, the prevalence of ROD in Nigeria is not known, however the prevalence of ROD in University of Nigeria Teaching Hospital Enugu using skeletal x-ray was reported to be $3.35 \%$ (Odenigbo, 2003). With the increase in the number of patients with CRF requiring or undergoing dialysis across Nigeria, it has becomes necessary to study the extent of ROD in CRF patient with or without dialysis.

\section{Methodology}

\subsection{Place of study}

The study was done at the University of Benin Teaching Hospital (UBTH)) Benin City, which is a 420-bedded tertiary hospital with Renal Unit that offers dialysis. Majority of 
patients come from Edo State (where the hospital is situated), Delta, Anambra, Ondo, and Oyo States.

\subsection{Type of study}

The study was prospective, descriptive, Clinico-pathological and hospital based.

\subsection{Subjects}

The study group was made up of consecutive chronic renal failure patients attending the University of Benin Teaching Hospital (UBTH).

\subsection{Inclusion criteria}

1. Ultrasonographic findings of bilaterally shrunken kidneys of less than $9 \mathrm{~cm}$ bipolar diameter.

2. Persistently elevated serum creatinine concentration above $175 \mu \mathrm{mol} / \mathrm{l}$.

3. Patients aged between 18years and 65years.

The subjects were recruited after obtaining informed consent from them (and / or relations when necessary). Also ethical approval was sought and obtained from the Ethical Committee of the UBTH.

\subsection{Exclusion criteria}

Exclusion from the study included:

1. Patients aged below 18years

2. Those who have had or are on vitamin D therapy

3. Those with chronic liver disease

4. Those who indulge in excessive alcohol intake

5. Post menopausal women.

6. Bed ridden patients.

7. Patient with metastatic bone disease.

\subsection{Sample size}

Fisher's formula for determining sample size was used. This is:

$$
\mathrm{N}=\frac{\mathrm{Z} 2 \mathrm{Pq}}{\mathrm{d} 2}
$$

$\mathrm{n}=$ number of sample size

$\mathrm{p}=$ prevalence of the problem $=0.06 \%$

$\mathrm{q}=1-\mathrm{P}$

$z=95 \%$ confidence interval $=1.96$

$\mathrm{d}=$ level of precision $=0.05$

$\mathrm{n}=86.7=87$

However since this was a pilot study, sample size of approximately $50 \%$ of above (that is 50 ) was used. 
A total of 115 patients were screened by:

Taking of a detailed history and physical examination at the initial contact with the patients with view to determining whether the patients had features suggestive of CRF and also whether patients met the inclusion criteria. Those with obvious exclusion criteria were dropped from the study at this level. This resulted in the exclusion of 55 subjects.

Twenty-four hours urine was collected and used for estimation of creatinine clearance and 24hours urinary calcium. On the morning of the test $(8.00 \mathrm{am})$, patients emptied their bladder and discarded the urine. Subsequently, urine passed was put into a clean container until 8.00am the next day. At the end of the urine collection, $5 \mathrm{mls}$ of blood was collected from the patients for estimation of serum creatinine. The creatinine clearance was calculated by using the formula: $\mathrm{UV} / \mathrm{P}$, where $\mathrm{V}$ is the urine flow rate $(\mathrm{mls} / \mathrm{min})$. Normal values of creatinine clearance was taken as $105-150 \mathrm{mls} / \mathrm{min}$ while 24 hours urinary calcium was taken as $100-300 \mathrm{mg} / \mathrm{dl}$. Where it was necessary radiograph of the chest and lumbo-sacral spines were carried out to rule out metastatic bone lesion. An abdominal ultrasonographic scan was carried out. After these evaluations a total of 52 subjects were studied having met the inclusion criteria.

\subsection{Study design}

The eventual 52 subjects who satisfied the inclusion criteria were required to complete a researcher administered questionnaire which includes age, sex, occupation, dietary habits, clinical symptoms of ROD, frequency and regularity of dialysis. Physical examination was performed by the investigator.

Ten milliters $(10 \mathrm{ml})$ of venous blood was drawn from the remaining 60 patients from a suitable vein with loose fitting tourniquet. The blood sample was used to assay for serum alkaline phosphatase levels, bone specific alkaline phosphatase levels, serum albumin levels, calcium and phosphate levels.

Osteocalcin, hydroxyproline, parathyroid hormone and calcitriol assays were not carried out because of lack of necessary facilities. However, a surrogate for parathyroid hormone was taken as total serum alkaline phosphatase.

Glomerular filtration rate was determined by 24 hour urinary creatinine clearance. Also 24hour urine calcium was determined from the $24 \mathrm{hr}$ urine. Plain x-rays of the wrist/ phalanges of both hands and / or lumbo-sacral spine to include the pelvis was carried out looking out for features of osteodystrophy. Bone histology, though more sensitive in the diagnosis of ROD than radiographic evidence could not be done in live subjects because consent for the procedure was refused. 20 of the CRF patients died during the study. However, out of these, only 14 died in the hospital and the corpse deposited in the mortuary. Post mortem bone biopsies were done on 10 of the 14 bodies whose relations gave consent for the post mortem after obtaining consent from relations.

40 patients without the exclusion criteria and who did not have the have renal failure but attending out -patient clinic of UBTH, whose ages ranged from 18-65years were used as controls. 


\section{MATERIAL AND METHODS}

\subsection{Apparatus}

\subsubsection{X-ray machine - Watson RO1}

This is a standard machine with good resolution quality.

The procedure was carried out by an experienced radiographer using the posterior- anterior positions.

The film was read and reported by an experienced consultant Radiologist.

\subsubsection{Ultrasound machine}

Sonoace 1500 (Medison) 3.5 MHz sector probe was used. This is a standard machine with good resolution.

Renal ultrasound scan was carried out by an experience Sonographer

\subsection{Serum phosphate estimation}

This was done using Fiske-Subbarow method. This is a colorimetric method using FiskeSubbarow reagent.

The composition of the reagent is a follows:

Ammonium molybdate $-7 \mathrm{nM}$

Sulphuric acid $\quad-1.7 \mathrm{~N}$

Iron (11) Sulphate $\quad-8 \mathrm{Mm}$

\subsubsection{Principle}

The phosphate ion reacts with Molybdate to produce Phosphomolybdate, which is finally reduced to a molybdenum blue, which is photo metrically measured.

\subsubsection{Technique}

1. Three test tubes were labeled as: Blank -BL

\section{Standard -ST \\ Sample -SA}

2. $0.1 \mathrm{ml}$ of patient's blood sample was added to SA. $0.1 \mathrm{ml}$ of standard was added to ST. To all 3 test tubes were added $3.0 \mathrm{ml}$ of the reagent.

3. The content of each of the test tubes were mixed properly and allowed to stand for 10 minutes at room temperature $\left(20-25^{\circ} \mathrm{C}\right)$.

4. Reading was done using a spectrophotometer set at $650 \mathrm{nM}$ wavelength.

5. The concentration of inorganic phosphate in patient sample was calculated using the formula.

Inorganic phosphate $(\mathrm{mg} / \mathrm{dl})=\frac{\text { SA O.D } \times 4}{\text { ST O.D }}$

O.D $=\quad$ Optic Density

Normal value of serum phosphate was taken as $2.4-4.5 \mathrm{mg} / \mathrm{dl}$. 


\subsection{Measurement of total serum calcium}

The Cresolphtalein- Complexone method (CPC) was used for the determination of total serum calcium. This is a standard Colorimetric method. This like most calcium assays measures the total serum calcium although it is only the free calcium which constitutes 50$65 \%$ of total calcium that is biologically active.

\subsubsection{Principle}

CPC forms a violet colored complex with calcium. The absorbance of the colour produced was measured in a colorimeter using a Spectrophotometer at $575 \mathrm{nM}$ wavelength measured in a colorimeter using a spectrophotometer at $575 \mathrm{nM}$ wave length. Interference from magnesium was reduced by including 8-hydroxquinoline in the working CPC reagent. The Ethanediol in the reagent suppresses the ionization of the 0-Cresolphtalein and helps to give a clear solution. A correction was made when the patient's serum albumin level was below $40 \mathrm{~g} / 1$ using this formula:

Corrected serum albumin $=40-\frac{\text { albumin } \mathrm{g} / 1+\mathrm{Ca}^{2}}{40}$

\subsubsection{Method}

1. Two sets of four tubes were labeled as follows:

B-reagent blank, standard $(2 \mathrm{mmol} / \mathrm{l})$

C - Control; $\quad \mathrm{p}$ - patient.

2. $5 \mathrm{mls}$ of CPC reagent was added into each tube using a pipette

3. The following were added into each set of tubes using a pipette as follows:

B. - $0.05 \mathrm{mls}$ distilled water

$\mathrm{S}-0.05 \mathrm{mls}$ standard $(2 \mathrm{mmol} / 1)$

C- $0.05 \mathrm{mls}$ Control serum

$\mathrm{p}-0.05 \mathrm{mls}$ patient serum

The contents of each tube were mixed for several seconds.

4. Using clean Cuvettes, the absorbance of the solution were read in a colorimeter using a spectrophotometer set at $575 \mathrm{nM}$. The instrument was zero with a blank solution in tube B.

5. The concentration of $\mathrm{Ca}^{2+}$ in the patients sample was calculated with the following formula:

AT $=$ Absorbance of test or control

$$
\mathrm{Ca}^{2+}(\mathrm{mmo} 1 / \mathrm{L})=\frac{\mathrm{AT}}{\mathrm{AS}} \times 2
$$

AS $=$ Absorbance of standard

Serum calcium values of $8.5-10.5 \mathrm{mg} / \mathrm{dl}$ was taken as normal.

\subsection{Measurement of serum alkaline phosphatase}

This was done using the kind and king method (1954). This is a standard colorimetric method. 


\subsubsection{Princile}

4- amino antipyrine gives a red purple colour with compounds containing a phenolic group in the presence of alkaline oxidizing agents.

\subsubsection{Technique}

$2 \mathrm{mls}$ of buffer substrate was measured into each of the 2 test tubes and placed in water bath at $37^{\circ} \mathrm{C}$ for a few minutes. To one of the test tube (patients' test tube) was added $0.1 \mathrm{ml}$ of serum and the tubes were incubated for exactly 15 minutes. They were removed from the bath and $0.8 \mathrm{ml}$ of $0.5 \mathrm{M}$ sodium hydroxide and $1.2 \mathrm{ml}$ of $0.5 \mathrm{M}$ (the blank) was added to both tubes, $1 \mathrm{ml}$ of amino- antipyrine reagent and $1 \mathrm{ml}$ of potassium ferricyanide were added. For the standard, $1 \mathrm{ml}$ of buffer and $1 \mathrm{ml}$ of phenol standard containing $0.01 \mathrm{mg}$ of phenol was taken. For the standard blank, $1.1 \mathrm{ml}$ of buffer and $1 \mathrm{ml}$ of water was taken to both tubes, and then sodium hydroxide, bicarbonate amino-antipyrine and ferricyanide was added as above. It was read with a spectrophotometer set at 520 millimicrons. Serum alkaline phosphatase (King- Amstrong unit per 100mls) was derived from the formula:

Serum alkaline phosphatase $=\quad$ Reading of unknown - Reading of blank $\times 10$

$$
\text { Reading of standard - Reading of standard blank }
$$

Total serum alkaline phosphatase values of 25-95 IU/L was taken as normal

\subsection{Determination of bone specific alkaline phospatse}

This was done by curve-fitting of inhibition kinetic as popularized by (Statland et al, 1972).

\subsubsection{Principle}

After the determination of the total serum alkaline phosphatase as described above, the serum is heated for 13 minutes at $56^{\circ} \mathrm{C}$ to inactivate the bone- type isoenzyme. The sera are now read as in the determination of the total serum alkaline phosphatase using a spectrophotometer set at 520 millimicron wavelength.

The concentration of serum alkaline phosphatase excluding the bone isoenzyme was determined as was done for total alkaline phosphatase using a spectrophotometer set at 520millimicron wavelength. The bone isoenzyme was determined by subtracting this value from the total alkaline phosphatase. Values of bone specific alkaline phosphatase level greater than $50 \%$ of total serum alkaline phosphatase shows significant contribution from bone iso-enzyme.

\subsection{Bone histology (post mortem)}

\subsubsection{Procedure}

1. The autopsy specimen biopsy was taken from the pelvic bone.

2. Decalcification: The piece of bone biopsied was decalcified by emersion in $10 \%$ nitric acid for 2 days.

3. Dehydration: the decalcified bone was dehydrated by passing the bone through ascending grades of alcohol. $(70 \%, 90 \%, 100 \%)$ respectively. 
4. Clearing of excess alcohol: to rinse off excess alcohol that could be in the tissue, it was rinsed with xylene or toluene.

5. Impregnation with paraffin wax: the tissue was then impregnated with paraffin wax, and subsequently embedded into paraffin block.

6. Cutting into sections: the tissue embedded into paraffin block was cut into section of about 5 micron thick.

7. The cut section was then placed on a slide and allowed to dry for a minimum of $30 \mathrm{~min}$.

8. Staining process: heamatin and eosin stains were used.

9. Reading of slide: the slide was read and reported by an experienced histopathologist.

\subsection{Statistical analysis}

Data analysis was done using SPSS package, and the storage was in Microsoft excel. Data are expressed in tabular, bar chart and prose forms. Mean standard deviation and percentages of all data were derived. Odd ratio was used to measure strength of association between ROD and their relative risk.

The t-test and chi-squared test were used to determine the differences in means of the CRF group and control.

$\mathrm{P}$ value of less than 0.05 was regarded as significant.

\section{Results}

\subsection{Characteristics of subjects studied}

A total of 115 patients were screened for the study. 52 of them were studied, having met the inclusion criteria. This was made up of $30(58 \%)$ males and $22(42 \%)$ females. 40 age and sex matched controls, made up of $22(55 \%)$ males and 18 (45\%) females were also studied. The age range of the study population was $18-65$ years. $3(5 \%)$ of the CRF patients were in the age range less than 30 years, $16(30 \%)$ were in the 31 - 40 years age range, $13(25 \%)$ and 14 (26\%) were in the age range 41 - 50 years and 51 - 60 years respectively, while $6(11 \%)$ were in the age range greater than 60 years. The peak incidence of CRF was in the $31-40$ years age range. The mean age of the CRF patients and controls were $42.5 \pm 11.6$ years and $40.4 \pm$ 11.3 years respectively (refer to table 1 ).

\begin{tabular}{|l|l|l|}
\hline AGE (YEARS) & CRF GROUP $(\mathrm{n}=52)$ & CONTROL GROUP $(\mathrm{n}=40)$ \\
\hline & Frequency $(\%)$ & Frequency $(\%)$ \\
\hline$<30$ & $3(5 \%)$ & $7(17 \%)$ \\
$31-40$ & $16(30 \%)$ & $12(30 \%)$ \\
$41-50$ & $13(25 \%)$ & $10(25 \%)$ \\
$51-60$ & $14(26 \%)$ & $7(17 \%)$ \\
$>60$ & $6(11 \%)$ & $4(10 \%)$ \\
\hline
\end{tabular}

Table 1. Age and sex distribution of both CRF and control groups. 


\begin{tabular}{|c|c|c|c|}
\hline Characteristics & $\begin{array}{l}\text { CRF Group }(n=52) \\
\text { Mean } \pm \text { SD }\end{array}$ & $\begin{array}{l}\text { Control Group } \\
(n=40) \text { Mean } \pm S D\end{array}$ & $\begin{array}{l}\mathrm{P} \\
\text { Value }\end{array}$ \\
\hline Sex & $\mathrm{M}(30), \mathrm{F}(22)$ & $\mathrm{M}(22), \mathrm{F}(18)$ & \\
\hline Age (Yrs) & $42.5 \pm 11.6$ & $40.38 \pm 11.3$ & $>0.05$ \\
\hline \multicolumn{4}{|l|}{ Renal sizes (cm) } \\
\hline Right & $8.33 \pm 0.5$ & $11.99 \pm 0.32$ & $<0.05$ \\
\hline Left & $8.16 \pm 0.5$ & $11.92 \pm 0.33$ & $<0.05$ \\
\hline Creatinine clearance (mls/min) & $9.8 \pm 6.7$ & $126 \pm 7.3$ & $<0.05$ \\
\hline Total alkaline phosphatase (iu/l) & $129.4 \pm 21.6$ & $43.73 \pm 8.31$ & $<0.05$ \\
\hline $\mathrm{BAP}(\mathrm{iu} / \mathrm{l})$ & $83.12 \pm 21.6$ & $21.8 \pm 4.11$ & $<0.05$ \\
\hline Serum calcium (mg/dl) & $6.9 \pm 2.3$ & $9.12 \pm 0.5$ & $<0.05$ \\
\hline Serum phosphate (mg/dl) & $6.1 \pm 1.9$ & $3.20 \pm 0.6$ & $<0.05$ \\
\hline 24 hours urine calcium $(\mathrm{mg} / \mathrm{dl})$ & $1.7 \pm 2.37$ & $3.8 \pm 1.76$ & $>0.05$ \\
\hline Serum creatinine (mg/dl) & $7.16 \pm 2.4$ & $0.8 \pm 0.15$ & $<0.05$ \\
\hline Blood urea (mg/dl) & $123.8 \pm 39.8$ & $24.4 \pm 5.6$ & $<0.05$ \\
\hline Serum protein $(\mathrm{gm} / \mathrm{dl})$ & $3.2 \pm 0.60$ & $4.46 \pm 0.52$ & $>0.05$ \\
\hline
\end{tabular}

Table 2. Characteristics of CRF and control group.

In the age ranges $<30$ years and $31-40$ years, the mean creatinine clearance were $7 \pm 1.83$ $\mathrm{mls} / \mathrm{min}$ and $12.6 \pm 2.16 \mathrm{mls} / \mathrm{min}$ respectively. In the age ranges $41-50$ years and $51-60$ years, the mean creatinine clearances were $8.6 \pm 3.2 \mathrm{mls} / \mathrm{min}$ and $8.2 \pm 2.6 \mathrm{mls} / \mathrm{min}$ respectively. In the age range $>60$ years, the mean creatinine clearance was $11.8 \pm$ $5.2 \mathrm{mls} / \mathrm{min}$. Creatinine clearance was lowest in the $<30$ years age range. This is represented in figure1.

\subsection{Symptoms of renal osteodydtrophy (ROD)}

The symptoms suggestive of ROD in the study population include bone pain and pruritus. $7(14 \%)$ of the CRF group had symptoms. This was made up of $5(71 \%)$ that had bone pain and $2(29 \%)$ that had pruritus. $5(12 \%)$ of the control group had bone pain. None had pruritus. The symptom of bone pain was commoner in males compared to females. Of those that had bone pain, $4(80 \%)$ were males while $1(20 \%)$ was a females. Pruritus was equally as common in both sexes ( 1 male and 1 female).

The entire patients that had pruritus in the CRF group had elevated serum alkaline phosphatase, hyperphosphataemia and elevated calcium-phosphate product. There was a statistically significant correlation between bone pain and creatinine clearance $(r=-0.3)$, such that bone pain occurred more commonly in patients with end stage renal disease (ESRD). 
Only $1(1 \%)$ patient in the CRF group had radiological evidence of Rugger Jersey Spine. Radiological evidence of osteoarthritis was found in $3(60 \%)$ and $2(40 \%)$ of the patients that had bone pain in the CRF and control group respectively (see Table 3 ).

\begin{tabular}{|l|l|l|l|l|l|l|l|l|l|}
\hline \multicolumn{2}{|l|}{ Patients } & \multicolumn{3}{l|}{ Characteristics } \\
\hline & Sex & Age (Yrs) & $\begin{array}{l}\text { Serum Ca } \\
(\mathrm{mg} / \mathrm{dl})\end{array}$ & $\begin{array}{l}\text { Serum P04 } \\
(\mathrm{mg} / \mathrm{dl})\end{array}$ & $\begin{array}{l}\text { Serum } \\
\text { Alk } \\
\text { Phosp } \\
(\mathrm{iu} / \mathrm{l})\end{array}$ & $\begin{array}{l}\text { Ca x P04 } \\
\mathrm{mg}^{2} / \mathrm{dl}^{2}\end{array}$ & $\begin{array}{l}\text { X-ray } \\
\text { Findings }\end{array}$ & $\begin{array}{l}\text { Crcl } \\
(\mathrm{mls} / \mathrm{min})\end{array}$ & Symptoms \\
\hline 1. & $\mathrm{M}$ & 40 & 9.8 & 14 & 142 & 137.2 & - & 12 & Pruritus \\
2. & $\mathrm{M}$ & 46 & 6.4 & 9.9 & 156 & 64.4 & RJS & 10.6 & Pain \\
3. & $\mathrm{M}$ & 52 & 4 & 5.4 & 128 & 21.6 & OA & 12.6 & Pain \\
4. & $\mathrm{~F}$ & 48 & 10.2 & 9 & 106 & 19.8 & OA & 9.6 & Pruritus \\
5. & $\mathrm{~F}$ & 56 & 4.5 & 13 & 136 & 58.5 & OA & 7.2 & Pain \\
6. & $\mathrm{M}$ & 62 & 5.6 & 9.9 & 99 & 64.4 & OA & 8.5 & Pain \\
7. & $\mathrm{M}$ & 64 & 7.7 & 6.5 & 127 & 48.1 & $*$ & 16 & Pain \\
\hline
\end{tabular}

RJS $=$ Rugger Jersey spine, $\mathrm{PO}_{4}=$ Phosphate, $\mathrm{Ca}=$ Calcium, Alk Phosp = Alkaline phosphate, $\mathrm{Crcl}=$ Creatinine clearance, $\mathrm{OA}=$ Osteoarthritis.

Table 3. Characteristics of CRF patients symptomatic of ROD.

\subsection{Creatinine clearance of subjects}

The mean creatinine clearance in the CRF and control groups was $9.8 \pm 6.7 \mathrm{mls} / \mathrm{min}$ and $126.2 \pm 7.4 \mathrm{mls} / \mathrm{min}$ respectively. There was a statistically significant difference between both means $(\mathrm{p}<0.05)$.

Table 4 shows the distribution of subjects according to creatinine clearance. In the CRF group, $47(90 \%)$ had ESRD, with creatinine clearance $<15 \mathrm{mls} / \mathrm{min}, 4(8 \%)$ had creatinine clearance of $15-29 \mathrm{mls} / \mathrm{min}$, and $1(2 \%)$ had creatinine clearance $30-59 \mathrm{mls} / \mathrm{min}$. All controls had creatinine clearance $>95 \mathrm{mls} / \mathrm{min}$ (see Table 4 ).

\begin{tabular}{|c|c|c|c|c|}
\hline \multirow[t]{3}{*}{ Creatinine clearance (mls/min) } & \multicolumn{4}{|l|}{ Frequency } \\
\hline & \multicolumn{2}{|l|}{$\begin{array}{l}\text { CRF group } \\
\mathrm{n}=52\end{array}$} & \multicolumn{2}{|c|}{$\begin{array}{l}\text { Control group } \\
\mathrm{n}=40\end{array}$} \\
\hline & Frequency & $\%$ & Frequency & $\%$ \\
\hline$>95$ & - & - & 40 & $100 \%$ \\
\hline $30-59$ & 1 & 2 & - & \\
\hline $15-29$ & 4 & 8 & - & - \\
\hline$<15$ & 47 & 90 & - & - \\
\hline
\end{tabular}

Table 4. Distribution of subjects according to creatinine clearance. 


\subsection{Renal ultrasonographic scan of subjects}

The mean kidney sizes in the CRF group was $8.2 \pm 0.5 \mathrm{~cm}$ and $8.3+0.5 \mathrm{~cm}$ for the right and left kidneys respectively, while that of the control was $12.10 \pm 0.33 \mathrm{~cm}$ and $12.02 \pm 0.33 \mathrm{~cm}$ for the right and left kidneys respectively. $52(100 \%)$ patients in the CRF group had shrunken kidneys $(<11 \mathrm{~cm})$.

There was a weak positive correlation between renal sizes and creatinine clearance, with $\mathrm{r}=$ 0.12 and $r=0.17$ for the right and left kidneys respectively (see Table 5).

\begin{tabular}{|l|l|l|l|l|}
\hline \multirow{2}{*}{ Renal sizes $(\mathrm{cm})$} & \multicolumn{2}{|l|}{ Frequency } & \multicolumn{2}{l|}{$\begin{array}{l}\text { CONTROL GROUP } \\
(\mathrm{n}=40)\end{array}$} \\
\cline { 2 - 5 } & $\begin{array}{l}\text { CRF GROUP } \\
(\mathrm{n}=52)\end{array}$ & Right & Left \\
\cline { 2 - 5 } & Right & Left & Re & - \\
\hline Small size $(<9 \mathrm{~cm})$ & 51 & 51 & - & - \\
$9-10.9 \mathrm{~cm}$ & 1 & 1 & - & 40 \\
Normal size & - & - & 40 & - \\
$(11-12 \mathrm{~cm})$ & - & - & - & 40 \\
Large size $>12 \mathrm{~cm}$ & - & - & - & - \\
\hline
\end{tabular}

Table 5. Renal sizes of subjects on abdominal ultrasonographic scan.

Normal kidney size: 11 -12cm (Brenner and Rector. The kidney vol.1, $6^{\text {th }}$ edition 2000).

\subsection{Serum calcium of subjects}

The mean serum calcium in the CRF and control groups was $6.9 \pm 2.3 \mathrm{mg} / \mathrm{dl}$ and $9.12 \pm$ $0.53 \mathrm{mg} / \mathrm{dl}$ respectively. This difference between the means was statistically significant $(\mathrm{p}<0.05)$.

Table 6 shows the pattern of serum calcium concentration in the study population. In the CRF group, $37(71 \%)$ patients had hypocalcaemia $(<8.5 \mathrm{mg} / \mathrm{dl}), 3(6 \%)$ had hypercalcaemia $(>10.5 \mathrm{mg} / \mathrm{dl}$, while $12(23 \%)$ had normal calcium levels $(8.5-10.5 \mathrm{mg} / \mathrm{dl})$. In the control group, 39 (97\%) patients had normal calcium levels, while only $1(3 \%)$ had hypocalcaemia. None in the control group had hypercalcaemia. There was a weak positive correlation between serum calcium and total alkaline phosphate in the CRF group $(r=0.04)$, such that as the serum alkaline phosphate was increasing, the serum calcium was decreasing. Amongst the CRF patients with total serum alkaline phosphate of <25iu/l, the mean serum calcium was $6.4 \pm 1.6 \mathrm{mg} / \mathrm{dl}$, while in the group with total serum alkaline phosphate of $25-$ $95 \mathrm{iu} / \mathrm{l}$, the mean serum calcium was $7.9 \pm 3.0 \mathrm{mg} / \mathrm{dl}$, and in the group with total serum alkaline phosphate of $>95 \mathrm{iu} / \mathrm{l}$, the mean serum calcium was $6.8 \pm 1.8 \mathrm{mg} / \mathrm{dl}$. There was an insignificant correlation between serum calcium and creatinine clearance $(r=0.007)$. Amongst the CRF patients with creatinine clearance of $<15 \mathrm{mls} / \mathrm{min}$, the mean serum calcium was $5.2 \pm 2.4 \mathrm{mg} / \mathrm{dl}$, while in the group that had creatinine clearance of 15 $29 \mathrm{mls} / \mathrm{min}$, the mean serum calcium was $6.3 \pm 2.1 \mathrm{mg} / \mathrm{dl}$, and in the group with creatinine clearance of $>30 \mathrm{mls} / \mathrm{min}$, the mean serum calcium was $8.4 \pm 1.6 \mathrm{mg} / \mathrm{dl}$. Mean serum calcium tends to be lower in ESRD patients (see table 6). 


\begin{tabular}{|l|l|l|}
\hline Serum Calcium $(\mathrm{mg} / \mathrm{dl})$ & $\begin{array}{l}\text { CRF group } \\
\mathrm{n}=52\end{array}$ & $\begin{array}{l}\text { Control group } \\
\mathrm{n}=40\end{array}$ \\
\hline $\begin{array}{l}\text { Hypocalcaemia } \\
(<8.5 \mathrm{mg} / \mathrm{dl})\end{array}$ & $37(71 \%)$ & $1(3 \%)$ \\
$\begin{array}{l}\text { Normal levels } \\
(8.5-10.5 \mathrm{mg} / \mathrm{dl})\end{array}$ & $12(23 \%)$ & $39(97 \%)$ \\
$\begin{array}{l}\text { Hypercalcaemia } \\
(>10.5 \mathrm{mg} / \mathrm{dl})\end{array}$ & $3(6 \%)$ & - \\
\hline
\end{tabular}

Table 6. The distribution of subjects according to serum calcium.

\subsection{Serum phosphate of subjects}

The mean serum phosphate in the CRF group was $6.1 \pm 2.0 \mathrm{mg} / \mathrm{dl}$, and this was significantly higher than the mean serum phosphate of $3.2 \pm 0.6 \mathrm{mg} / \mathrm{dl}$ in the control group $(\mathrm{p}<0.05)$. Table 7 shows the pattern of serum phosphate in both the CRF and control groups. In the CRF group, 41 (79\%) patients had hyperphosphataemia, while 11 (21\%) had normal serum phosphate levels. No patient had hypophosphataemia. In the control group, all the 40 $(100 \%)$ patients had normal serum phosphate levels. There was insignificant but positive correlation between serum phosphate and creatinine clearance $(\mathrm{r}=0.1)$ and bone pain $(\mathrm{r}=$ 0.4). (See Table 7)

\begin{tabular}{|l|l|l|}
\hline $\begin{array}{l}\text { Serum phosphate } \\
(\mathrm{mg} / \mathrm{dl})\end{array}$ & $\begin{array}{l}\text { CRF group } \\
\mathrm{n}=52\end{array}$ & $\begin{array}{l}\text { Control group } \\
\mathrm{n}=40\end{array}$ \\
\hline $\begin{array}{l}\text { Hypophosphataemia } \\
(<2.4 \mathrm{mg} / \mathrm{dl})\end{array}$ & - & - \\
$\begin{array}{l}\text { Normal phosphate } \\
\text { Level }(2.4-4.5 \mathrm{mg} / \mathrm{dl})\end{array}$ & $40(100 \%)$ \\
$\begin{array}{l}\text { Hyperphosphataemia } \\
(>4.5 \mathrm{mg} / \mathrm{dl})\end{array}$ & $11(21 \%)$ & - \\
\hline
\end{tabular}

Table 7. Pattern of serum phosphate in subjects.

Amongst the CRF patients with serum alkaline phosphatase of $<25 \mathrm{iu} / \mathrm{l}$, the mean serum phosphate was $5.1 \pm 0.9 \mathrm{mg} / \mathrm{dl}$, while in the group with serum alkaline phosphatase of $25-$ $95 \mathrm{iu} / \mathrm{l}$, serum phosphate was $6.5 \pm 1.2 \mathrm{mg} / \mathrm{dl}$, and in the group with serum alkaline phosphatase of $>95 \mathrm{iu} / 1$ the mean serum phosphate was $6.2 \pm 1.4 \mathrm{mg} / \mathrm{dl}$. Thus, there was a weak but negative correlation between serum phosphate and total serum alkaline phosphatase $(\mathrm{r}-0.15)$, such that when total serum alkaline phosphatase was increasing, the serum phosphate also increased.

Amongst the CRF patients with creatinine clearance of $>30 \mathrm{mls} / \mathrm{min}$, the mean serum phosphate was $4.4 \pm 1.2 \mathrm{mg} / \mathrm{dl}$, while in the groups with creatinine clearance of 15 $29 \mathrm{mls} / \mathrm{min}$ and $<15 \mathrm{mls} / \mathrm{min}(\mathrm{ESRD})$, the mean serum phosphate was $6.6 \pm 1.1 \mathrm{mg} / \mathrm{dl}$ and $6.2 \pm 1.3 \mathrm{mg} / \mathrm{dl}$ respectively. As the creatinine clearance tended towards ESRD, the serum phosphate rises. There was a positive correlation between serum phosphate and creatinine clearance $(\mathrm{r}=0.10)$. 


\subsection{Serum alkaline phosphatase of subjects}

The mean total serum alkaline phosphatase in the CRF group was $129.4 \pm 21.6 \mathrm{iu} / 1$, while that of the control was $43.73 \pm 8.3 \mathrm{iu} / 1$. There was a statistically significant difference between both means ( $\mathrm{p}<0.05) .41(79 \%)$ of the CRF group had elevated total serum alkaline phosphatase levels, 8 (15\%) had normal levels, $3(6 \%)$ had low levels, while all controls had normal levels. Of the $41 \mathrm{CRF}$ patients that had elevated total serum alkaline phosphatase levels, all $(100 \%)$ had $>50 \%$ of their alkaline phosphatase levels, from bone isoenzyme (bone specific alkaline phosphatase). Only 1 (2\%) CRF patient had radiological evidence of ROD (Rugger Jersey Spine). Total serum alkaline phosphatase correlated positively with creatinine clearance $(r=0.06)$ and bone pain $(r=0.4)$.

Amongst the CRF group with creatinine clearance of $>30 \mathrm{mls} / \mathrm{min}$ the mean total alkaline phosphatase was $105 \pm 6.1 \mathrm{iu} / \mathrm{l}$, while in the groups with creatinine clearance of 15 $29 \mathrm{mls} / \mathrm{min}$ and $<15 \mathrm{mls} / \mathrm{min}(\mathrm{ESRD})$, the mean alkaline phosphatase were $124 \pm 4.6 \mathrm{iu} / \mathrm{l}$ and $143+5.6 \mathrm{iu} / 1$ respectively (see Table 8 ).

\begin{tabular}{|l|l|l|}
\hline $\begin{array}{l}\text { Total serum alkaline } \\
\text { phosphatase }(\mathrm{iu} / \mathrm{l})\end{array}$ & $\begin{array}{l}\text { CRF group, } \mathrm{n}=52 \\
\text { Frequency }(\%)\end{array}$ & $\begin{array}{l}\text { Control group, } \mathrm{n}=40 \\
\text { Frequency }(\%)\end{array}$ \\
\hline $\begin{array}{l}\text { Increased levels }(>95 \mathrm{iu} / \mathrm{l}) \\
\text { Normal levels }(25-95 \mathrm{iu} / 1\end{array}$ & $\begin{array}{l}41(79 \%) \\
8(15 \%)\end{array}$ & - \\
Decreased levels $(<25 \mathrm{iu} / \mathrm{l})$ & $3(6 \%)$ & - \\
\hline
\end{tabular}

Table 8. Distribution of CRF and control groups according to serum alkaline phosphatase.

\subsection{Calcium and phosphate products of CRF subjects}

The mean calcium $x$ phosphate products in the CRF group was $42.8 \pm 21.6 \mathrm{mg}^{2} / \mathrm{dl}^{2}$ while that of the control was $28.21 \pm 2.4 \mathrm{mg}^{2} / \mathrm{dl}^{2}$. There was a statistically significant difference in both means $(\mathrm{p}<0.05)$. Table 9 shows distribution of calcium $\mathrm{x}$ phosphate product amongst the CRF patients. 3 (5\%) of the CRF patients had calcium $x$ phosphate product $>70 \mathrm{mg}^{2} / \mathrm{dl}^{2}$. This was made up of $2(66 \%)$ males and $1(34 \%)$ female. $6(11 \%)$ patients had their calcium $x$ phosphate product between $52-70 \mathrm{mg}^{2} / \mathrm{dl}^{2}$. This was made up of $2(33 \%)$ males and $4(67 \%)$ females. $43(82 \%)$ patients had their calcium $\times$ phosphate products $<52 \mathrm{mg}^{2} / \mathrm{dl}^{2}$. This was made up of $26(60 \%)$ males and $17(40 \%)$ females. All 3 patients who had calcium $x$ phosphate product $>70 \mathrm{mg}^{2} / \mathrm{dl}^{2}$ died during the period of study and showed evidence of ROD on postmortem bone biopsy.

Normal Ca $\times$ P04 product $=<70 \mathrm{mg}^{2} / \mathrm{dl}^{2}$.

\subsection{Urinary calcium excretion in study group}

The mean 24 hours urinary calcium in the CRF group was $68.4 \pm 12.8 \mathrm{mg} / \mathrm{dl}$, and $162+$ $40.4 \mathrm{mg} / \mathrm{dl}$ in the control group. This difference in means is statistically significant $(\mathrm{p}<0.05)$. There was an insignificant correlation between 24hours urinary calcium and creatinine clearance, and serum calcium $(r=-0.16)$ and $(r=0.02)$ respectively. There was a statistically significant correlation between 24 hours urinary calcium and total serum alkaline phosphatase $(r=0.38)$ but no significant correlation with sex $(r=0.79)$, age $(r=0.46)$ or bone paint $(r=0.23)$. 


\begin{tabular}{|c|c|c|c|c|c|c|c|}
\hline \multicolumn{4}{|l|}{ MALES } & \multicolumn{4}{|c|}{ FEMALES } \\
\hline $\begin{array}{l}\text { Serial } \\
\text { number }\end{array}$ & $\begin{array}{l}\text { Serum } \\
\text { P04 } \\
(\mathrm{mg} / \mathrm{dl})\end{array}$ & $\begin{array}{l}\text { Serum } \\
\text { Ca } \\
(\mathrm{mg} / \mathrm{dl})\end{array}$ & $\begin{array}{l}\mathrm{Ca} \times \mathrm{P} 04 \\
\text { product } \\
\left(\mathrm{mg}^{2} / \mathrm{dl}^{2}\right)\end{array}$ & $\begin{array}{l}\text { Serial } \\
\text { number }\end{array}$ & $\begin{array}{l}\text { Serum } \\
\text { Ca } \\
(\mathrm{mg} / \mathrm{dl})\end{array}$ & $\begin{array}{l}\text { Serum } \\
\text { P04 } \\
(\mathrm{mg} / \mathrm{dl})\end{array}$ & $\begin{array}{l}\mathrm{Ca} \times \mathrm{P} 04 \\
\text { product } \\
\left(\mathrm{mg}^{2} / \mathrm{dl}^{2}\right)\end{array}$ \\
\hline 1. & 6 & 5.1 & 30.6 & 1 & 6 & 5.2 & 31.2 \\
\hline 2. & 5 & 4.8 & 24.0 & 2 & 8.7 & 3.8 & 33.1 \\
\hline 3. & 4.2 & 5.8 & 24.4 & 3 & 5 & 6.5 & 32.5 \\
\hline 4. & 6 & 7.3 & 43.8 & 4 & 9.8 & 5.8 & 56.8 \\
\hline 5. & 8.9 & 4.9 & 43.6 & 5 & 10.6 & 6.4 & 67.8 \\
\hline 6. & 8.5 & 5.3 & 45.1 & 6 & 9.2 & 7.5 & 69.0 \\
\hline 7. & 3 & 4.1 & 12.3 & 7 & 4 & 11.1 & 44.4 \\
\hline 8. & 6.2 & 5.8 & 36.0 & 8 & 5.6 & 4.9 & 27.4 \\
\hline 9. & 9.7 & 4.8 & 46.6 & 9 & 3.7 & 4.4 & 16.3 \\
\hline 10 & 6.8 & 3.2 & 21.8 & 10 & 6 & 6.4 & 38.4 \\
\hline 11. & 5 & 2.7 & 13.5 & 11 & 6.2 & 7.4 & 45.9 \\
\hline 12. & 5.4 & 8.7 & 47.0 & 12 & 6.5 & 8.6 & 55.9 \\
\hline 13. & 9.9 & 6.5 & 64.4 & 13 & 5.7 & 7.8 & 44.5 \\
\hline 14. & 6.5 & 7 & 45.5 & 14 & 6.8 & 7 & 47.6 \\
\hline 15. & 5.4 & 4 & 21.6 & 15 & 7.6 & 4.8 & 36.5 \\
\hline 16. & 7.3 & 4.3 & 31.4 & 16 & 7.8 & 4.2 & 32.8 \\
\hline 17. & 8.6 & 6 & 51.6 & 17 & 4.8 & 6.4 & 30.7 \\
\hline 18. & 8.6 & 3 & 25.8 & 18 & 5.8 & 6.5 & 37.7 \\
\hline 19. & 4.9 & 7.3 & 48.1 & 19 & 10.2 & 5.8 & 53.4 \\
\hline 20. & 5.4 & 7.1 & 34.8 & 20 & 4.6 & 10.2 & 91.8 \\
\hline 21. & 5.4 & 3.2 & 17.3 & 21 & 7.1 & 4.6 & 35.0 \\
\hline 22. & 14 & 9.8 & 17.3 & 22 & 4.9 & 7.1 & 34.8 \\
\hline 23. & 7 & 6.9 & 137.2 & & & & \\
\hline 24. & 13 & 4.5 & 48.3 & & & & \\
\hline 25. & 9 & 12.5 & 58.5 & & & & \\
\hline 26. & 6.5 & 5.9 & 112.5 & & & & \\
\hline 27. & 8.3 & 60.1 & 38.4 & & & & \\
\hline 28. & 3 & 6.1 & 50.6 & & & & \\
\hline 29. & 5.6 & 5.8 & 17.4 & & & & \\
\hline 30. & 5.4 & 5.9 & 37.0 & & & & \\
\hline Mean & 6.99 & 5.83 & 42.02 & & 6.84 & 6.47 & 43.79 \\
\hline Std Dev. & 2.5 & 2.1 & 26.4 & & 1.9 & 1.9 & 16.8 \\
\hline
\end{tabular}

Table 9. Serum Calcium, Serum phosphate and calcium $x$ phosphate product of CRF patients.

\subsection{Radiological evidence of ROD}

Of the patient that had symptoms of ROD, $5(71 \%)$ had bone pain while $2(29 \%)$ had pruritus. Only 1 (20\%) of the 5 patients that had bone pain showed radiological evidence of Rugger-Jersey spine (see appendix 1), constituting 9\% of the CRF group. Table 10 shows the 
characteristics of the only patient with radiological evidence of Rugger Jersey spine. In the control group, 5 (21\%) had bone pain. Of these, 2 (40\%) constituting $5 \%$ of the control group, had radiological evidence of osteoarthritis while Radiological evidence of osteoarthritis was found in $3(60 \%)$ patients that had bone pain in the CRF group.

APPENDIX 1: X-RAY OF THE SPINE SHOWING RUGER-JERSEY APPEARANCE.

NOTE THE ALTERNATING BANDS OF HYPO-DENSITY AND HYPERDENSITY INDICATING OSTEOPOROSIS AND OSTEOSCLEROSIS RESPECTIVELY.

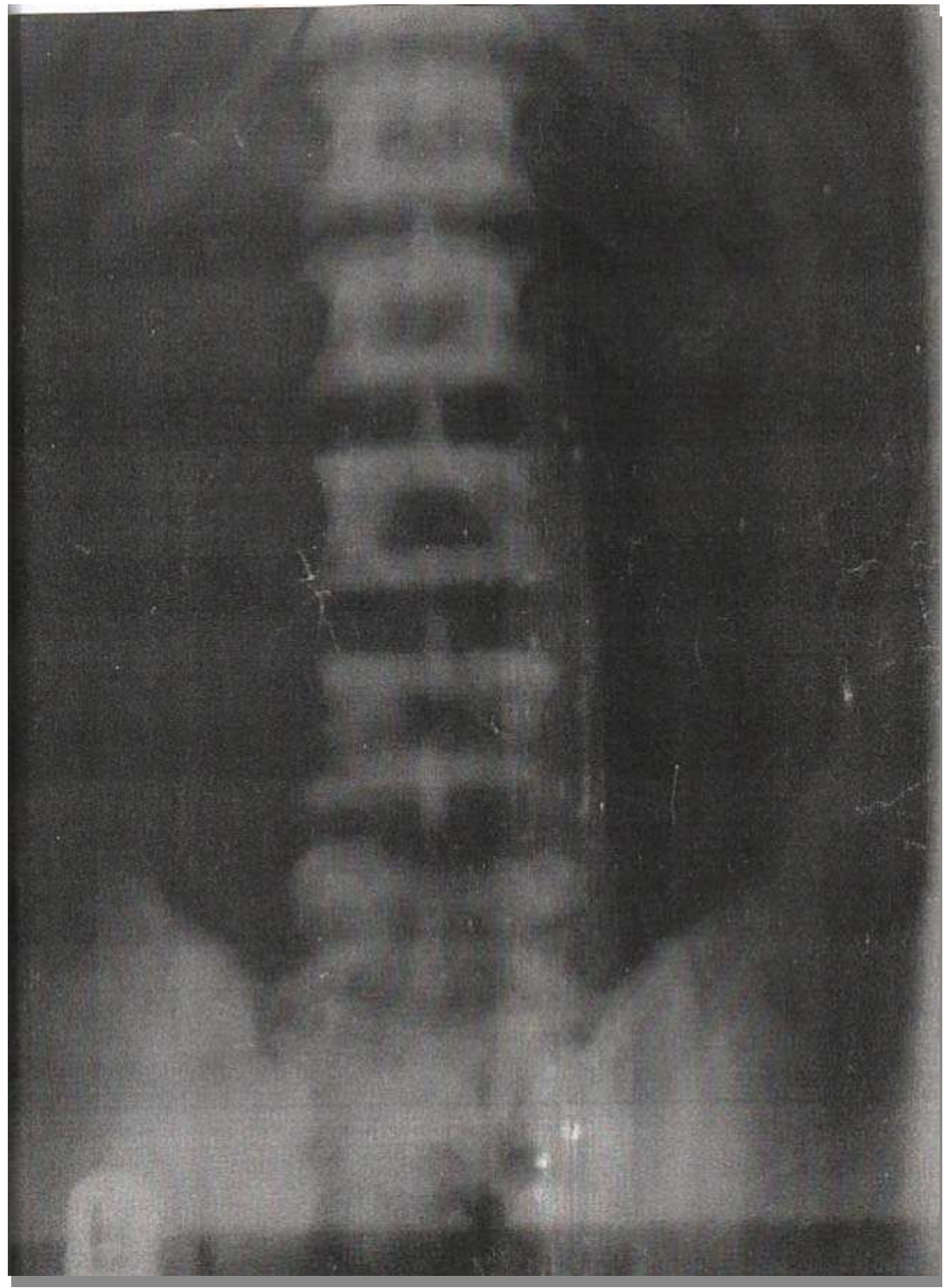




\begin{tabular}{|l|l|ll|l|l|l|l|l|}
\hline $\begin{array}{l}\text { Age } \\
(\text { Years })\end{array}$ & Sex & $\begin{array}{l}\text { RS } \\
(\mathrm{cm}) \\
\text { Left }\end{array}$ & Right & $\begin{array}{l}\text { Serum Ca } \\
(\mathrm{mg} / \mathrm{dl})\end{array}$ & $\begin{array}{l}\text { Alk } \\
\text { Phosp } \\
(\mathrm{iu} / \mathrm{l})\end{array}$ & $\begin{array}{l}\text { Serum } \\
\mathrm{P04} \\
(\mathrm{mg} / \mathrm{dl})\end{array}$ & $\begin{array}{l}\text { Ca x P04 } \\
\left(\mathrm{mg}^{2} / \mathrm{dl}^{2}\right)\end{array}$ & $\begin{array}{l}\text { Crcl } \\
(\mathrm{mls} / \mathrm{min})\end{array}$ \\
\hline 54 & $\mathrm{M}$ & 7.8 & 7.6 & 6.5 & 156 & 9.9 & 64.4 & 6.0 \\
\hline
\end{tabular}

(Rugger Jersey Spine).

$\mathrm{Crcl}=$ Creatinine clearance, Alk phosp $=$ Alkline phosphatase,

P04 $=$ Phosphate, $\mathrm{Ca}=$ Calcium, $\mathrm{RS}=$ Renal Size .

Table 10. Characteristics of the only patient with radiological evidence of ROD.

\subsection{Histological evidence of rod on postmortem bone biopsy}

10 Postmortem bone biopsies were carried out. This was made up of 7 (70\%) males and 3 $(30 \%)$ females. $9(90 \%)$ had histological evidence of ROD, while 1 had normal bone histology. Of the 9 that had histological evidence, $6(66 \%)$ were males while $3(34 \%)$ were females. $6(66 \%)$ had Osteitis Fibrosa. This was made up of $4(50 \%)$ males and $2(34 \%)$ females. 2 (22\%) had Osteomalacia, 1 each $(50 \%)$ of male and female, while $1(12 \%)$ male had evidence of mixed type ROD (see Appendices 2-4). All the patients who had histological evidence of ROD had their creatinine clearance $<15 \mathrm{mls} / \mathrm{min}$ (ESRD). 8 (88\%) of the patient with histological evidence of ROD did not have any radiological evidence of ROD.

All the patients that had bone histological evidence of ROD had elevated total serum alkaline phosphatase and serum phosphatase. There is a positive correlation between histological evidence of ROD and total serum alkaline phosphatase and serum phosphate, $(\mathrm{r}$ $=0.04)$ and $(r=0.036)$ respectively. There was no correlation between histological evidence of ROD and symptoms of ROD $(r=0.48)$, see table 11 .

\begin{tabular}{|l|l|l|l|l|l|l|l|}
\hline Patients & Gender & $\begin{array}{l}\text { Age } \\
\text { (Year) }\end{array}$ & $\begin{array}{l}\text { Histological } \\
\text { type }\end{array}$ & $\begin{array}{l}\text { Calcium } \\
(\mathrm{mg} / \mathrm{dl})\end{array}$ & $\begin{array}{l}\text { Phosp } \\
(\mathrm{mg} / \mathrm{dl})\end{array}$ & $\begin{array}{l}\text { Ca x P04 } \\
(\mathrm{mg} / \mathrm{dl} 2)\end{array}$ & $\begin{array}{l}\text { Total Alk. } \\
\text { Phosp } \\
(\mathrm{iu} / \mathrm{L})\end{array}$ \\
\hline 1 & $\mathrm{M}$ & 46 & OF & 6.8 & 9.9 & 64.4 & 156 \\
2 & $\mathrm{M}$ & 48 & OM & 12.5 & 9.0 & 112.5 & 140 \\
3 & $\mathrm{M}$ & 52 & OF & 5.3 & 8.5 & 45.1 & 122 \\
4 & $\mathrm{~F}$ & 46 & OM & 7.5 & 9.2 & 69.0 & 134 \\
5 & $\mathrm{M}$ & 39 & Mixed type & 8.7 & 5.4 & 47.0 & 138 \\
6 & $\mathrm{M}$ & 36 & OF & 9.8 & 14.0 & 137.5 & 152 \\
$* 7$ & $\mathrm{~F}$ & 48 & OF & 10.2 & 9.0 & 91.8 & 98 \\
8 & $\mathrm{M}$ & 40 & OF & 6.1 & 8.3 & 50.6 & 106 \\
9 & $\mathrm{~F}$ & 54 & OF & 6.4 & 10.6 & 67.8 & 146 \\
\hline
\end{tabular}

* Patient 7 had normal histology

$\mathrm{OF}=$ Osteitis Fibrosa, $\mathrm{OM}=$ Osteomalacia

Table 11. Characteristics of patients with bone histological evidence of ROD. 
The Prevalence of Renal Osteodystrophy in

APPENDIX 2: PHOTOMICROGRAMS OF BONE HISTOLOGY SHOWING OSTEITIS FIBROSA, OSTEOMALACIA AND OSTEITIS FIBROSA IN PATIENTS 1, 2 AND 3 RESPECTIVELY.

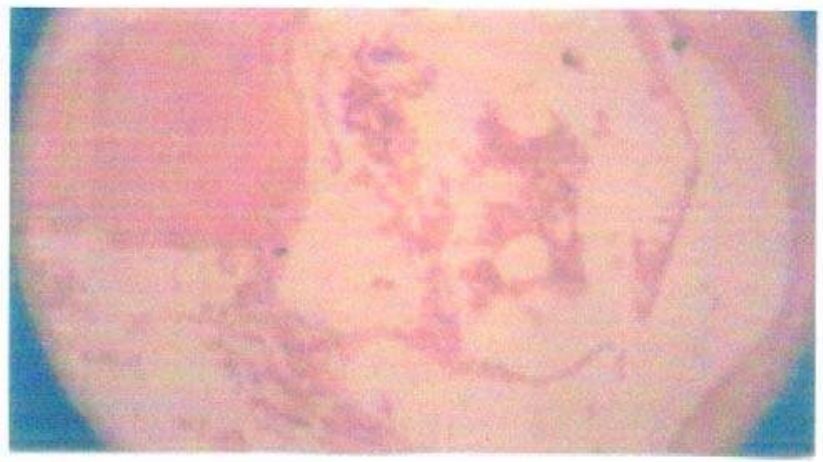

Osteitis fibrosa

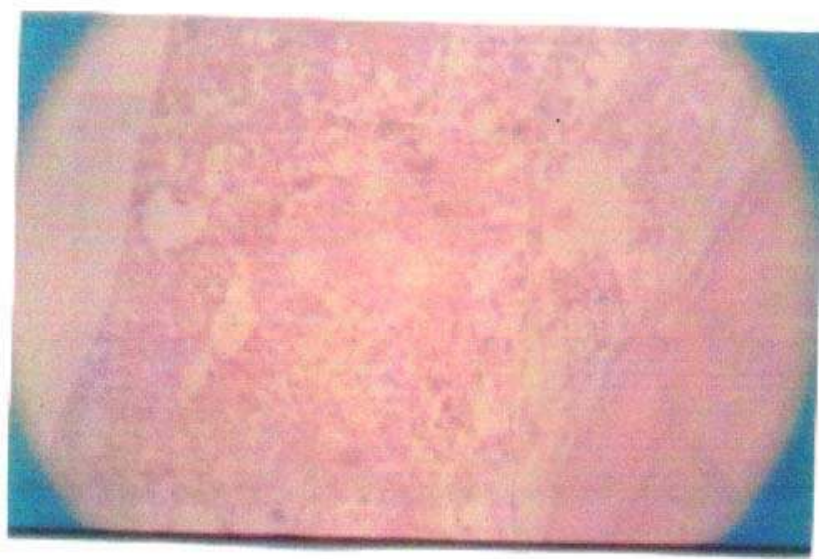

Osteomalacia

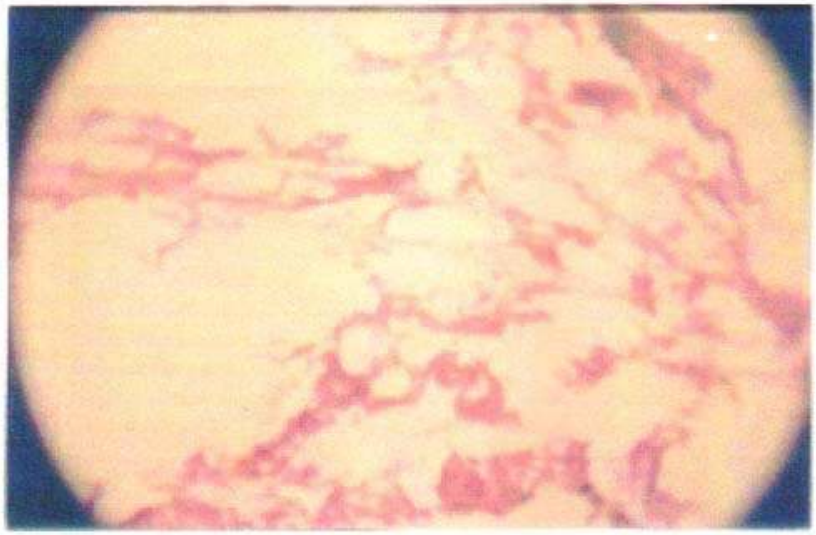

Osteitis fibrosa 
APPENDIX 3: PHOTOMICROGRAMS OF BONE HISTOLOGY SHOWING

OSTEOMALACIA, MIXED TYPE ROD AND OSTEITIS FIBROSA IN PATIENT4, 5 AND 6 RESPECTIVELY.

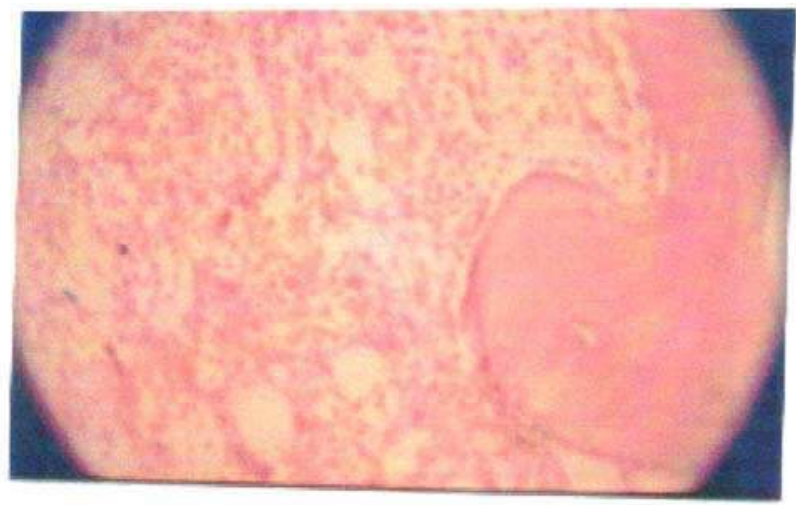

4

Osteomalacia

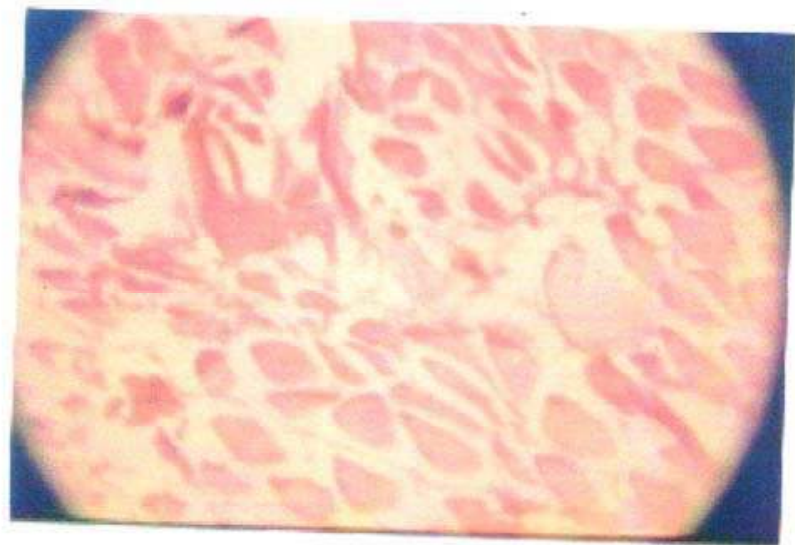

5

Mixed type ROD

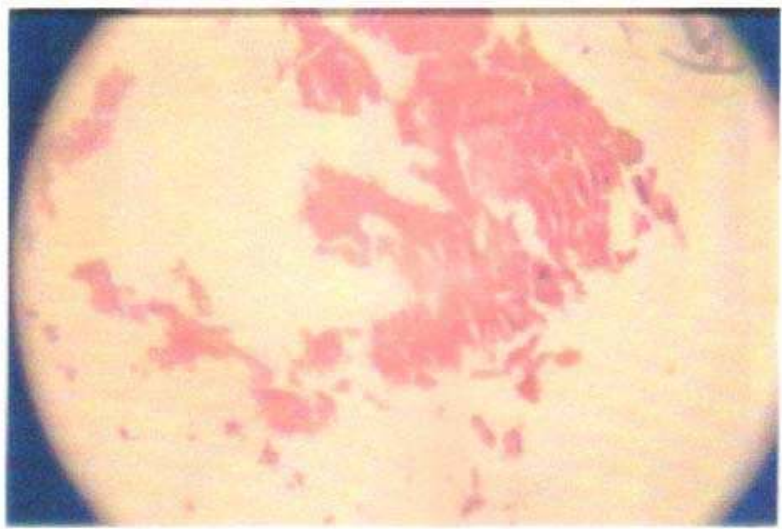

6

OSTEITIS FIBROSA 
APPENDIX 4: PHOTOMICROGRAMS OF BONE HISTOLOGY SHOWING NORMAL HISTOLOGY, OSTEITIS FIBROSA, OSTEITIS FIBROSA AND OSTEITIS FIBROSA IN PATIENT 7, 8, 9 AND 10 RESPECTIVELY.
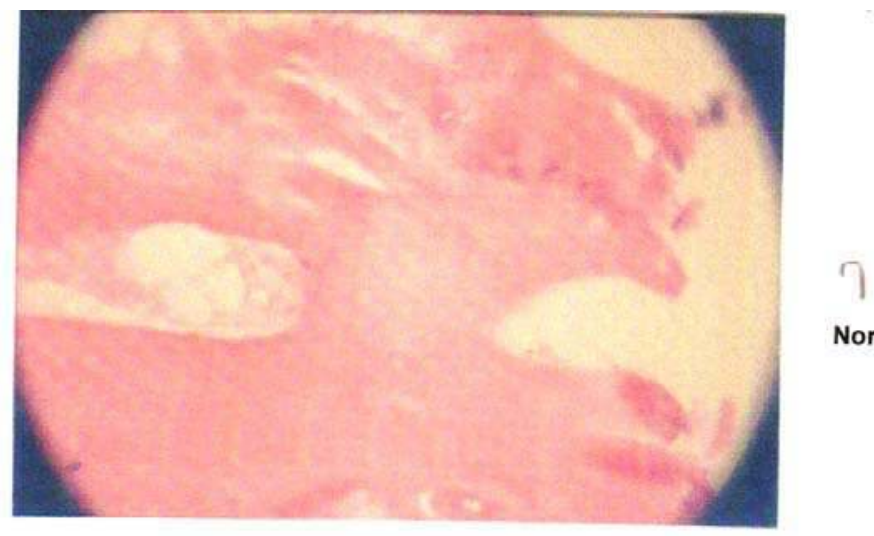

Normal

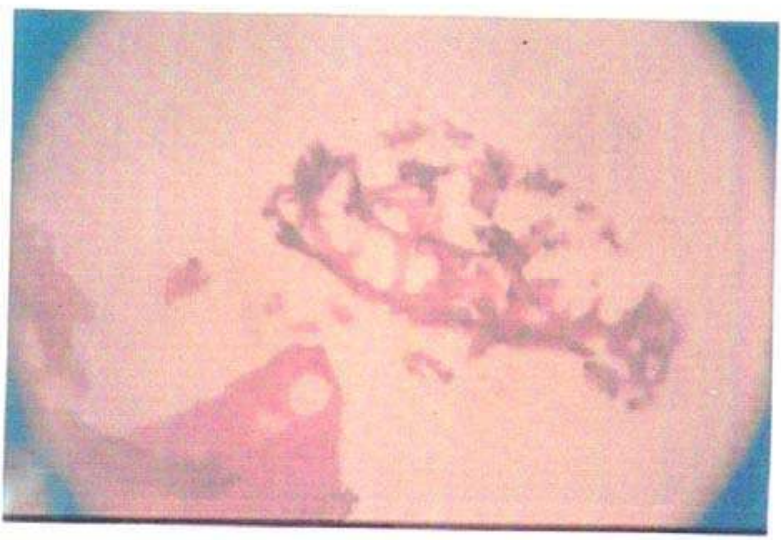

Osteitis fibrosa

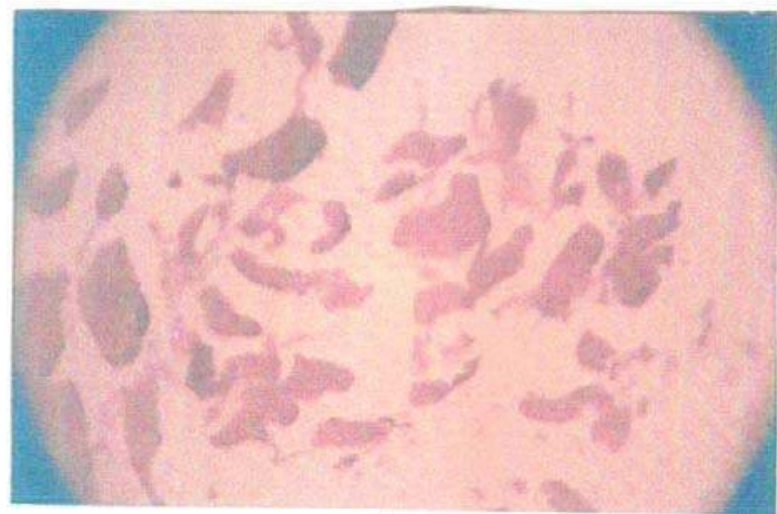

Osteitis fibrosa 


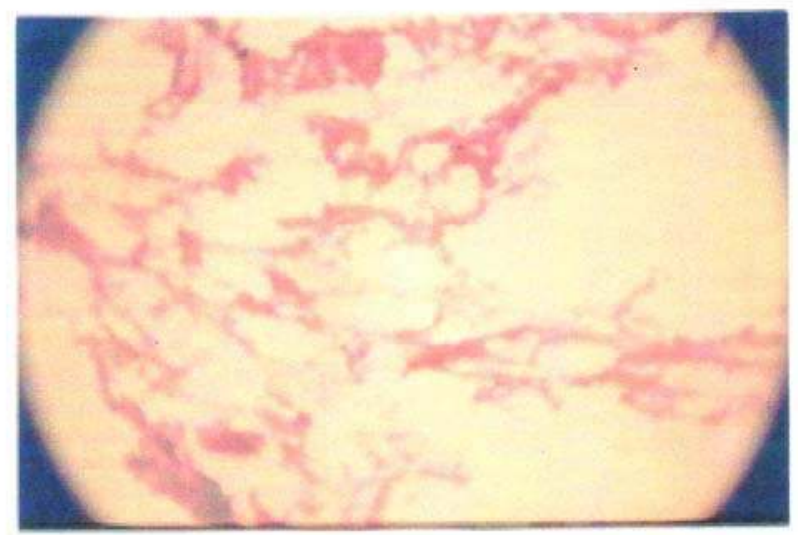

OSTEITIS FIBROSA

\begin{tabular}{|l|l|l|l|l|l|l|l|}
\hline Patients & Gender & $\begin{array}{l}\text { Age } \\
(\text { Year })\end{array}$ & $\begin{array}{l}\text { Histological } \\
\text { type }\end{array}$ & $\begin{array}{l}\text { Calcium } \\
(\mathrm{mg} / \mathrm{dl})\end{array}$ & $\begin{array}{l}\text { Phosp } \\
(\mathrm{mg} / \mathrm{dl})\end{array}$ & $\begin{array}{l}\text { Ca x P04 } \\
\left(\mathrm{mg} / \mathrm{dl}{ }^{2}\right)\end{array}$ & $\begin{array}{l}\text { Total Alk. } \\
\text { Phosp } \\
(\mathrm{iu} / \mathrm{L})\end{array}$ \\
\hline 1 & $\mathrm{M}$ & 46 & OF & 6.8 & 9.9 & 64.4 & 156 \\
2 & $\mathrm{M}$ & 48 & OM & 12.5 & 9.0 & 112.5 & 140 \\
3 & $\mathrm{M}$ & 52 & OF & 5.3 & 8.5 & 45.1 & 122 \\
4 & $\mathrm{~F}$ & 46 & OM & 7.5 & 9.2 & 69.0 & 134 \\
5 & $\mathrm{M}$ & 39 & Mixed type & 8.7 & 5.4 & 47.0 & 138 \\
6 & $\mathrm{M}$ & 36 & OF & 9.8 & 14.0 & 137.5 & 152 \\
$* 7$ & $\mathrm{~F}$ & 48 & OF & 10.2 & 9.0 & 91.8 & 98 \\
8 & $\mathrm{M}$ & 40 & OF & 6.1 & 8.3 & 50.6 & 106 \\
9 & $\mathrm{~F}$ & 54 & OF & 6.4 & 10.6 & 67.8 & 146 \\
\hline
\end{tabular}

* Patient 7 had normal histology

$\mathrm{OF}=$ Osteitis Fibrosa, $\mathrm{OM}=$ Osteomalacia

Table 11. Characteristics of patients with bone histological evidence of ROD.

\section{Dicussion}

\subsection{Findings of the study}

This study was carried out to determine the prevalence of ROD in chronic renal failure in Benin City.

The main findings of the study suggest that:

1. Osteitis Fibrosa is the commonest type of ROD.

2. There is a correlation between histological evidence of ROD and biochemical maker (Alkaline Phosphatase).

3. The yield of ROD using radiological examination is low in our chronic renal patients. 
4. Radiological and biochemical evidence of ROD seems to be more prevalent in severe chronic renal failure (ESRD).

5. ROD may be more prevalent in males.

6. There is no correlation between symptoms of ROD and biochemical or radiological evidence of ROD. This suggests that many patients may have ROD with no symptoms.

7. Hypocalcaemia and hyperphosphataemia is prevalent in our CRF patients.

\subsection{Osteitis fibrosa is the commonest type of rod}

Osteitis Fibrosa is a form of high turnover bone disease as a result of hyperparathyroidism. PTH assay was not done because of lack of facility in our center. However serum alkaline phosphatase was used as a surrogate. $78 \%$ of the CRF patients had raised levels of total serum alkaline phosphatase which correlate well with PTH levels and histological features of secondary hyperparathyroidism. This is in agreement with the work done by Duursma et al, (1975); Ritz et al (1974) and Hruska et al (1978). 66\% of patients had Osteitis Fibrosa on histology. This finding agrees with the work of Jarava et al (1996) who found bone histological evidence of Osteitis Fibrosa cystica in 17 (85\%) out of 20 haemodialysis patients in England. Our findings also agrees with that of shin et al (1999) who found Osteitis Fibrosa as the commonest type of ROD in predialysis patients in Canada (44\%). This finding contradicts that if Coen et al (1996) who found mixed type ROD as the commonest type in predialysis CRF patient in England.

\subsection{There is correlation between histological evidence of rod and serum alkaline phoshatase}

In this study, it was found that $90 \%$ of patient had histological evidence of ROD on postmortem bone biopsy. This agrees with the finding Sanchez (2001), who found that $90 \%$ of patients with ESRD on maintenance dialysis have abnormal bone histology. Majority of patients are either predialysis or those who were not dialyzing adequately. It is known that once a patient start on maintenance, the prevalence of ROD increases. One of the contributing factors being aluminum deposition (from dialysate fluid), it means that the prevalence may even be higher if our patients are dialyzed adequately. In our study we found that all the patients that had histological evidence of ROD had elevated serum alkaline phosphatase levels. This finding may possibly be pointing to the fact that serum alkaline phosphatase can be used as a surrogate of parathyroid hormone as a predictor of ROD in our patients. This agrees with the finding of Urena et al, (1991) that in the absence of liver disease, serum alkaline phosphatase can be used to predict the presence of ROD. The finding is also in agreement with that of Duursma et al and Ritz et al who found that plasma alkaline phosphatase levels correlates with histological features of secondary hyperparathyroidism $(\mathrm{HPTH})$.

\subsection{The yield of rod using radiological examination is low in our chronic renal failure patients}

In our study, we found only $2 \%$ of ROD using radiological examination. This agrees with Odenigbo (2003) who found 3.35\% of ROD in Enugu using radiological examination. In this study, radiological evidence of ROD was not found in all $9(100 \%)$ patients who had histological evidence of ROD on postmortem bone biopsy. This agrees with the finding of 
Hodsons et al, (1981) that there is a disparity between the radiological and histological evidence of ROD. In a study in Germany, Hodsons et al found only 7(41\%) patients with radiological evidence of ROD out of 17 with histological evidence of ROD. Micheal et al (1998) found radiological features of ROD in 35\% of CRF patients in ESRD.

There are some reasons for the low prevalence of ROD using x-rays. Firstly, the conventional techniques for $\mathrm{x}$-ray contribute. Meama et al (1972) noted the phalanges to be normal in $67 \%$ if uremic patients using conventional techniques for X-ray films, and only $8 \%$ showed subperiosteal erosion. With the introduction of better films and the use of magnification techniques, only $26 \%$ appeared normal while $29 \%$ for exhibited subperiosteal erosion. There is no facility for magnification technique in the center where the study was done. Secondly, it has been reported that more than $50 \%$ of bone can be lost without any evidence in a radiograph, because only the cortical bone is clearly noted, and an important loss of cancellous bone should occur before radiological feature of ROD can be appreciated (Poznanki, 1993). Perhaps the fact that CRF patients in our environment have infrequent haemodialysis and do not live long enough for these changes to be detected on x-ray studies may be contributory to the low yield of ROD using radiological examination.

\subsection{Radiological and biochemical evidence of rod is more prevalent in esrd patients}

In our study, the only patient who had radiological evidence of ROD had a creatinine clearance of $6 \mathrm{mls} / \mathrm{min}$. $90 \%$ of the CRF patients had creatinine clearance $<15 \mathrm{mls} / \mathrm{min}$ (ESRD). The entire patients who had creatinine clearance $<15 \mathrm{mls} / \mathrm{min}$ had elevated serum alkaline phosphatase levels. Theses finding agree with the findings of Coen et al (1996) that adynamic bone disease is commoner $\mathrm{n}$ early stages of renal failure, while Osteomalacia and Osteitis Fibrosa cystica tend to occur as resistance to PTH develops, a situation which occurs in ESRD.

\subsection{ROD may be more prevalent in males}

In this study, the one patient who had radiological evidence of ROD was a male. Also, of the 9 patients that had histological evidence of ROD, 6(66\%) were males, while 3(34\%) were females, with a male- female ratio of 2:1, this finding is in contrast to the finding of Odenigbo et al (2003) in a study carried out at Enugu where ROD was found to be more prevalent in females. The finding also contradicts that of Couttenye et al (1997) who showed that women seem to develop hyperparathyroidism whereas men seems to more frequently develop aplastic bone disease. The reason why men in this study showed evidence of ROD more than women may be due to the fact that there were more men in this study, particularly in the group of 10 patients that had postmortem biopsy. However, the number of patients studied was small for a general statement to be made on gender difference.

\subsection{There is no correlation between symptoms of rod and biochemical or radiological evidence}

In the study, 7 (14\%) of the CRF subjects had symptoms suggestive of ROD. Of these, 5(71\%) had bone pain while $2(29 \%)$ had radiological evidence of ROD ('Rugger Jersey" spine), while $3(80 \%)$ had radiological features of osteoarthritis. This agrees with the finding of Odenigbo, who reported that out of the 11 patients who had bone pain, none had radiological evidence of $\mathrm{ROD}$, but all patients who had radiological evidence of 
Osteoarthritis (Odenigbo 2003). This study also agrees with the work of Harowin et al (1987) who found a high incidence of joint symptoms and radiological abnormalities in his group of Canadian patient, not necessarily due osteodystrophy.

\subsection{Hypocalcaemia and hyperphosphataemia is prevalent in our crf patients}

In the study the mean serum calcium of CRF subject was $5.83 \pm 2.1 \mathrm{mg} / \mathrm{dl}$. $37(71 \%)$ of CRF subjects had hypocalcaemia $(<8.5 \mathrm{mg} / \mathrm{dl})$. This finding agrees with that of Slatoposky et al (1986). Calcium supplementation is a known modality for the treatment of hypocalcaemia. The mean serum phosphate of CRF patients in this was $6.1 \pm 2.0 \mathrm{mg} / \mathrm{dl}$. 41 (79\%) had hyperphosphataemia $(>4.5 \mathrm{mg} / \mathrm{dl})$. This agrees with finding of Slotoposky et al (1986) who demonstrated hyperphosphataemia even in moderate CRF. Dietary phosphate restriction and phosphate binding are effective methods of control of hyperphosphataemia.

\subsection{Conclusion and recommendations}

\subsubsection{Conclusion}

The findings of this study suggest that ROD which is a complication of chronic renal failure does exist in our environment. The study has also shown that Osteitis Fibrosa is the commonest type of ROD, and that ROD may be commoner in males. The study showed that in majority of patients with ESRD there is biochemical evidence. This finding may possibly be pointing to the fact that clinical features are a poor guide to the presence of ROD. Before now, it was thought that ROD hardly existed in our chronic renal failure patients, because they did not live long enough to manifest it. Though the findings of this study they agree with that, going by the low incidence of ROD using clinical symptoms and radiological methods, it is possible that in the nearest future, ROD may become more prevalent in on society. This is because there is now an increase in the availability of dialysis in many centers across the Nation, with possibility that many CRF patients may live long enough to develop ROD. The findings of this study suggest that serum alkaline phosphatase assay, a surrogate of parathyroid hormone, may be a good guide to the presence of ROD in our CRF patients. Majority of patients had hypocalcaemia and hyperphosphataemia.

\subsubsection{Recommendations}

It is hereby recommended that:

1. In all chronic renal failure patients, ROD should be anticipated. Serum calcium, phosphate, alkaline phosphatase should be done routinely.

2. Dietary restrictions of phosphate should be enforced in our chronic renal failure patient as well as the use of phosphate binders,

3. Calcium supplementation should be routinely part of the management of our chronic renal failure patients.

4. Control of hyperparathyroidism in our chronic renal failure patient will be an integral part of management of CRF patients.

\subsubsection{Limitation of the study}

This study was faced with some limitations. It was not possible to carry out bone biopsies for live patients because of lack of consent from the patients. However, postmortem bone 
biopsy was carried out instead; it was also not possible to assay parathyroid hormone because of lack of facility for its assay. In its place, serum alkaline phosphatase was used as a surrogate. There is no doubt that alkaline phosphatase is influenced by several factors and so is non-specific. It was also not possible to measure serum and tissue aluminum in the study.

\section{References}

Adelejun T.A., Akinsola. Hypertension induced chronic renal failure: clinical features, management and prognosis. WAJM . 1988 17(2): 104-108.

Adetuyibi A, Akinsanya J.B, Onadeko BO. Analysis of the cause of death on the medical wards of the UCH, Ibadan over 14years period (1960-1973). Trans. Roy. Soc. Trop.Med. Hyp. 1976; 70: 466-73.

Akinsola, W, Odesanmi WO, Ogunniyi JO, Ladipo G.O.A. Diseases causing renal failure in Nigeria - a prospective study of 100 cases. Afr. J. med. Sc. 1989, 18: 131-5

Baker LRL. Renal Disease. In: Kumar P, Clark M(eds). Clinical medicine, $4^{\text {th }}$ edn. W.B Saunders. Philadelphia. 1999: 572-573.

Brenner and Rector. The kidney vol.1, $6^{\text {th }}$ edition 2000

Gold $\mathrm{CH}$, Isaacson $\mathrm{C}$, Levin J. The pathological bases of end stage renal disease in Blacks. South Africa Med. J. 1990; 19: 103-6.

Coen G, Ballantini P, Bonucci E. Bone Markers in the diagnosis of low turnover ostrodystrohy in haemodialysis patients. Nephrol Dial transplant. 1996, 11: A41.

Coen G, Ballanti P, Bonucci E, Calabria S, Centorrino M, Fassino V. Bone markers in the diagnosis of low turnover osteodystrophy in haemodialysis patients. Nephrol-Dialtransplant. 1998; 13(9): 2294-302.

Couttenye M M, D' Haese PC., Deng J T, High prevalence of a dynamic bone disease diagnosed European CAPD population. Nephrol. Dial. Transplant 1997; 12: 21442150.

Cottenye M.M. D'Haese P.C, Verschoren W J, Behets G.J, Schrooten I, De-Broe M.E. Low bone tunrnover in patients with renal failure. Kid. Int. 1999; 56 Suppl. 73: 70-6.

Duursma S,A, Vonkesteren R.G., Visser W J. serum alkaline phosphate: its relationship to bone cell and its Significance as an indicator for vit $\mathrm{D}$ treatment in Patients with renal insufficiency. In Norman WW, Schaefer K, Grigoleit HG (eds): vit D and problems related to uremic bone disease. Walter de Gruyter, Berlin 1975; 167.

Jarava C, Armas J R, Sagueria M, Palma A. Bone alkaline phosphatase isoenzyme in renal osteodystrophy. Nephrol dial transplant 1996: 11: 43-46.

Kadiri S, Arijie A. Temporal variations and meterological factors in hospital admission of chronic renal failure in South West Nigeria. West Africa J. Med. 1999, 18: 49-51.

Kadiri S. towards reducing the impact of chronic renal failure. Africa Health 2001; 23(2): 910.

Harowin P, lecomte - Houcke M, Flipo RM. Current aspects of osteoarticular pathology in patients undergoing haemodialysis. Study of 80 patients. Laboratory and pathologic analysis. Discussion of the pathogenic mechanism J. Rheumafol. 1987; 14: 748-9.

Hartmut M; Marie-Claude F. Renal bone diease: An unmet challenge for the nephrologist: Kidney Int. 1990; 38(2): 193-205. 
Hodsons E M, Howman - Gilles RB, Evans RB, The diagnosis of renal oesteodystrophy; A comparison of technetium99. Pyrophosphate bone scintigraph with other techniques. Chine Nephrol 1981; 16:24-28.

Hruska K A, Teitelbaum SL, Kopelman R: The predictability of the histologic features of uremic bone disease by non-invasive techniques. Metab bone Dis Relat. Res 1978; 12: 393.

Mate-Kole M, Affram K, Lee SJ et al. Hypertension and end-Stage renal failure in tropical Africa. J. Hum. Hypertens. 1993; 7: 443-6.

Meema HE, Robinovich S, Meama $S$ et al. Improved radiological diagnosis of azotemic osteodystrophy. Radiology. 1972; 102: 1-10.

Michael L J, Brenner BM, Bone, phosphate and calcium abnormalities in chronic renal failure: In 15 ${ }^{\text {th }}$ ed; Harrisons principles of internal medicine; E. Braunwald, A Facuci, D Kasper et al. Mc Graw Hill Medical Publishing Division, Jackson W Y, USA 1998: 1517.

Odenigbo C.U. The prevalence and radiological markers of ROD in patients with chronic renal failure in Enugu FMCP, National Postgraduate Medical College of Nigeria May 2003.

Ojogwu L.I. The Pathological Basis of end-stage renal disease in Nigerians: experience from Benin City. West Afr.J. Med.1990;9: 193-6.

Ojogwu L.I. The Clinical assessment of Heamodialysis Machine in the management of kidney failure. Nig. J.Biomedical Engineering 2001;(1):19-26.

Poznanki A K, Radiological Evaluation of bone mineral in children. In Favus M J (ed) primer on metab bone diseases and disorders of mineral metabolism. Raven press NewYork 1993; 115.

Ritz E, Malluche H H, Bommer J: Metabolic bone disease in patients on haemodialysis. Nephron. 1974; 12:393.

Slatoposky EA, Weerts C, Lopez -Hilker S et al: Calcium Carbonate as a phosphate binder in patients with chronic renal failure undergoing dialysis. N Engl J med. 1986, 315: 157-161.

Sanchez OP. Prevention and treatment of renal osteodystrophy in children with chronic renal insufficiency and end stage renal diaseses; Semin Nepphrol 2001;21 (5): 44150.

Shin SK, Kim Hs, et al. Renal osteodystrophy in predialysis patients: Ethic difference? Perit Dial int. 1999; 19(suppl): S402-7.

Statland BE, Nishi HH, Young DS. Serum alkaline phosphatase: total activity and isoenzyme determination made by use of the centrifugal fast analyzer. Clin chem. 1972; 18: 1488-74.

Urena P, De-Vernejoul MC. Circulating biochemical markers of bone remodeling in uremic patients. Kid.Int. 1991; 55(6): 2141-56

Mate-Kole M, Affram K, Lee SJ et al. Hypertension and end-Stage renal failure in tropical Africa. J. Hum. Hypertens. 1993; 7: 443-6.

Odenigbo C.U. The prevalence and radiological markers of ROD in patients with chronic renal failure in Enugu FMCP, National Postgraduate Medical College of Nigeria May 2003.

Ojogwu L.I. The Pathological Basis of end-stage renal disease in Nigerians: experience from Benin City. West Afr.J. Med.1990;9: 193-6. 
Ojogwu L.I. The clinical assessment of heamodialysis machine in the management of kidney failure. Nig. J.Biomedical Engineering 2001;(1):19-26.

Sanchez OP. Prevention and treatment of renal osteodystrophy in children with chronic renal insufficiency and end stage renal diaseses; Semin Nepphrol 2001; 21 (5): 44150 . 


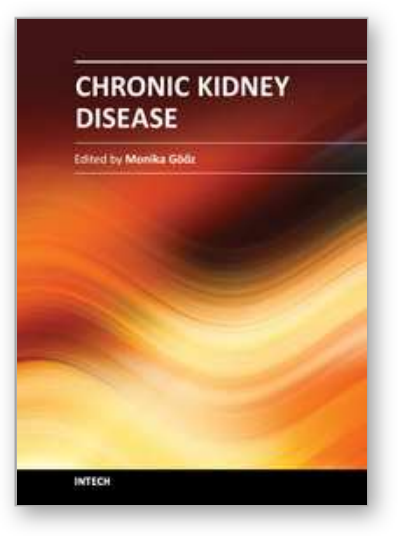

\author{
Chronic Kidney Disease \\ Edited by Prof. Monika Göőz
}

ISBN 978-953-51-0171-0

Hard cover, 444 pages

Publisher InTech

Published online 16, March, 2012

Published in print edition March, 2012

Chronic kidney disease is an increasing health and economical problem in our world. Obesity and diabetes mellitus, the two most common cause of CKD, are becoming epidemic in our societies. Education on healthy lifestyle and diet is becoming more and more important for reducing the number of type 2 diabetics and patients with hypertension. Education of our patients is also crucial for successful maintenance therapy. There are, however, certain other factors leading to CKD, for instance the genetic predisposition in the case of polycystic kidney disease or type 1 diabetes, where education alone is not enough.

\title{
How to reference
}

In order to correctly reference this scholarly work, feel free to copy and paste the following:

U. R. Onyemekeihia, C. O. Esume, E. Unuigbe, E. Oviasu, L. Ojogwu (2012). The Prevalence of Renal Osteodystrophy in Chronic Renal Failure Patients in Urban Niger Delta of Nigeria, Chronic Kidney Disease, Prof. Monika Göőz (Ed.), ISBN: 978-953-51-0171-0, InTech, Available from:

http://www.intechopen.com/books/chronic-kidney-disease/the-prevalence-of-renal-osteodystrophy-in-chronicrenal-failure-patients-in-urban-niger-delta-of-nig

\section{INTECH}

open science | open minds

\section{InTech Europe}

University Campus STeP Ri

Slavka Krautzeka 83/A

51000 Rijeka, Croatia

Phone: +385 (51) 770447

Fax: +385 (51) 686166

www.intechopen.com

\section{InTech China}

Unit 405, Office Block, Hotel Equatorial Shanghai

No.65, Yan An Road (West), Shanghai, 200040, China 中国上海市延安西路65号上海国际贵都大饭店办公楼 405 单元

Phone: +86-21-62489820

Fax: $+86-21-62489821$ 
(C) 2012 The Author(s). Licensee IntechOpen. This is an open access article distributed under the terms of the Creative Commons Attribution 3.0 License, which permits unrestricted use, distribution, and reproduction in any medium, provided the original work is properly cited. 